\author{
ОРГАНІЗАЦІЙНО-ПЕДАГОГІЧНІ УМОВИ УПРАВЛІННЯ \\ ПЕДАГОГІЧНОЮ ВЗАЄМОДІЄЮ ВИКЛАДАЧА І СТУДЕНТА \\ У ПРОЦЕСІ ПІДГОТОВКИ ФАХІВЦІВ
}

\author{
ORGANIZATIONAL CONDITIONS OF THE TEACHER AND STUDENTS \\ PEDAGOGICAL INTERACTION MANAGEMENT IN PRESERVICE TRAINING
}

УДК 378.147 .34

DOI https://doi.org/10.32843/2663-

6085/2020/30-2.24

\section{Борова Т.А.,}

докт. пед. наук,

професор каседри педагогіки,

іноземної фрілології та перекладу

Харківського національного

економічного університету

імені Семена Кузнеця

\section{Маслова Н.І.,}

канд. фрілол. наук,

доцент кафедри іноземної фрілології

Комунального закладу «Харківська гуманітарно-педагогічна академія»

Харківської обласної ради

\section{Марчук А.A.,}

аспірантка кафедри педагогіки, іноземної фрілології та перекладу Харківського національного економічного університету імені Семена Кузнеця
Стаття присвячена визначенню організачійно-педагогічних умов управління педагогічною взаємодією викладача і студента у процесі підготовки майбутніх фрахівців. Зокрема, розкривається сутність поняття «адаптивного управління» як підгрунтя виокремлення умов управління взаємодією. Здійснено аналіз організаційно-педагогічних умов ефрективного управління взаємодією викладача і студента, що призводить до професійного зростання викладача та набуття необхідних для профресії компетентностей студентами. Основна увага зосереджується на таких умовах управління взаємодією, які спрямовані на самоорганізацію суб'єктів розвитку (ціннісні, емоційні та організаційні).

На основі методу моделювання розроблена схематична модель управління взаємодією викладача і студента на засадах адаптивного управління. Діагностичний метод анкетування та опитування дали змогу отримати результати управління взаємодією викладача і студента. Висвітлюються структурні компоненти організаційної основи взаємодії викладача і студента, які спрямовують їх спільну діяльність на зміни як у результаті навченості студентів, що охоплює не тільки пізнавальні та навчальні аспекти діяльності педагога, а й більш широке коло інших характеристик, включаючи емоційні, ціннісні, організаційні.

Аналіз основних иінностей студентів івикладачів дав змогу виявити спільні чіннісні підґрунтя приймати управлінські рішення щодо взаємодії викладача і студента та їх результативніть у роботі та навчанні. Сукупні результати статистичної обробки дали змогу об'єктивно визначити пріоритетні можливості вербальної та невербальноі поведінки викладачів у студентській аудитоpiї, що поліпшило мікроклімат і стосунки між викладачем і студентами, посилило умотивованість до навчання та досягнення вищих результатів у навчанні. Результати оцінювання вмінь діалогічної взаємодії у викладачів і студентів дали змогу виокремити основні засади організації взаємодії: відкрита комунікація, командна робота, важливість людей та урахування неоднорідності.

Ключові слова: організаційно-педагогічні умови управління взаємодією викладача $i$ студента, управління взаємодією викладача i студента, цінності, імедіативність, діалогічна взаємодія, адаптивне управління, схематична модель управління взаємодією викладача і студента на засадах адаптивного управління.
The article is devoted to one of the urgent problems of determining the organizational and pedagogical conditions of managing pedagogical interaction of the teacher and the student in the process of training future specialists. In particular, the essence of the concept of adaptive management as a basis for distinguishing the conditions of the interaction management is revealed. The analysis of organizational and pedagogical conditions of the effective management of the interaction of the teacher and the student that leads to professional growth of the teacher and the acquisition of certain competences by students necessary for the future profession is carried out. The main focus is on the conditions of interaction management, which ensure self-organization of development actors (value, emotional and organizational). Using the modeling method, a schematic model of teacher-student interaction management based on adaptive management has been developed. The diagnostic method of questionnaires and surveys made it possible to obtain the results of teacher-student interaction management. The structural components of the organizational basis of teacher-student interaction are highlighted, which direct their joint activities to change, it being not only the result of students' learning, covering not only cognitive and educational aspects of the teacher, but also a wider range of other characteristics, including emotional, value, organizational.

The analysis of the basic values of students and teachers made it possible to identify their common value foundations to make management decisions about the interaction of the teacher and the student and their effectiveness at work and study. The aggregate results of statistical processing made it possible to objectively determine the priority opportunities for verbal and nonverbal behavior of teachers in the student audience, which in turn, improved both the microclimate and the relations between teachers and students and, consequently increased motivation to achieve higher training results. The results of assessing the skills of dialogic interaction of teachers and students help to identify the basic principles of organizing this interaction: open communication, teamwork, the importance of people as well as the realization of heterogeneity.

Key words: organizational and pedagogical conditions of teacher-student interaction management, teacher-student interaction management, values, mediativeness, dialogic interaction, adaptive management, schematic model of teacher-student interaction management on the basis of adaptive management. 
Постановка проблеми в загальному вигляді. Нові перетворення у системі освіти спрямовані на підвищення якості підготовки фрахівця, що впливає на вимоги до рівня системності та комплексності профресійної підготовки випускників, до їх готовності успішно вирішувати основні завдання профресійної та соціальної діяльності відповідно до встановлених освітніх і професійних стандартів, а також стимулювати пошук науково-обґрунтованих і більш ефективних підходів до удосконалення системної організації освітнього процесу в закладах вищої освіти, його орієнтації на кінцеві результати. Виокремлення умов, які впливають на взаємодію викладача і студента, може призвести до есрективної спільної роботи, тобто до отримання більш якісного фрормування необхідних профресійних компетентностей як у викладачів, так і в студентів.

Аналіз останніх досліджень і публікацій. Останнім часом багато праць науковців присвячено питанню професійного розвитку фрахівця у вищій освіті. Це роботи В. Бондаря, О. Галуса, М. Гриньової, Н. Гузій, А. Деркача, А. Кузьмінського, Г. Дмитренка, 3. Курлянд, В. Пономаренка та інших. Питання адаптивного управління постійно досліджуються представниками Школи адаптивного управління (Г. Кравченко, Г. Поляковою, О. Почуєвою, З. Рябовою та іншими), керівником якої $€$ Г. Єльникова. Наукові пошуки дослідників Т. Борової, О. Гончар та інших щодо взаємодії викладача і студентів на різних підґрунтях теж знайшли втілення в системі вищої освіти.

Виділення не вирішених раніше частин загальної проблеми. Останніми роками продовжується пошук нових та удосконалення існуючих шляхів підвищення ефективності роботи викладачів. Такі процеси потребують безперервності у поновленні стилю роботи викладача, її структуризації та нових творчих підходів. Проте не досить уваги приділено підходам щодо управлінського складника взаємодії викладачів і студентів, які призводять до професійного розвитку науковопедагогічних працівників та здобуття якісної освіти студентами з урахуванням їхніх індивідуальностей

Метою статті $€$ аналіз організаційно-педагогічних умов ефективного управління взаємодією викладача і студента, що призводить до професійного зростання викладача та набуття необхідних для професії компетентностей студентами. Визначені такі завдання: обґрунтувати вибір шляхів профресійного розвитку викладачів і студентів, визначити умови, які впливають на покращення взаємодії викладачів і студентів, є основою для підвищення якості навчання.

Виклад основного матеріалу. Звертаючи увагу на те, що профресійний розвиток приводить людину до самореалізації, професійного самоза- доволення, реалізації свого потенціалу, нами було досліджено умови, які впливають на ефрективність управління взаємодією викладача і студента.

Ґрунтуючись на тому, що теорія адаптивного управління $€$ основою будь-якого професійного розвитку, оскільки адаптивне управління визнає пріоритет розвитку суб'єкта і здійснюється за допомогою процесів самоорганізації, а особливістю адаптивного управління $є$ активізація природних сил і механізмів розвитку людини (за Г. Єльниковою), ми розглянули умови, які забезпечують встановлення та активізацію зовнішнього і внутрішнього (рефлексія) зворотного зв'язку. Професійний розвиток на адаптивних засадах ґрунтується на діалогічній взаємодії учасників освітнього процесу, під час якої відбувається взаємоузгодження їх цілей, спрямованих на вирішення спільно визначених завдань [1].

Поняття адаптивного управління було визначено Г. Єльниковою як процес взаємовпливу, що викликає взаємопристосування поведінки суб'єктів діяльності на діа(полі)логічній основі, яка забезпечується спільним визначенням реалістичної мети з подальшим поєднанням зусиль і самоспрямуванням дій на ії̈ досягнення [1]. Таке тлумачення $€$ відправним моментом у розумінні поведінкових основ учасників освітнього процесу, оскільки в основу їх спільної діяльності покладено діалогічну взаємодію, яка розуміється як особливий рівень комунікативного процесу, що відповідає потребам людини в особистісному контакті, який відбувається на основі погодження особистих цілей людини та цілей суспільства (організації).

Взаємодію О. Гончар визначає як «складний багатобічний процес, під час якого має місце взаємозмінювання суб'єктів, що зумовлено їх взаємовпливом» [2, с. 15]. Якщо підґрунтям взаємовпливу суб'єктів є діалог, то відбувається комунікація, у процесі якої знаходиться спільна дія, що призводить до спільного вирішення завдань. Отже, діалогічна взаємодія - процес взаємовпливу суб'єктів діяльності у процесі спільного вирішення завдань на комунікативній основі.

Процес спільного вирішення завдань $€$ взаємовигідним, тому мотивація зростає з обох боків комунікантів. У такий спосіб відбувається внутрішній поштовх до дії, що сприяє її усвідомленню та більш продуктивному виконанню. Отже, початок діалогу між студентом i науково-педагогічним працівником викликає ситуацію напруженості, яка характеризується аналізом наявної ситуації, руйнуванням звичайних способів взаємодії, під час якої виникає ситуація нестабільності; усвідомлення неминучості встановлення узгодженої взаємодії з урахуванням реальних умов, що призводить до виникнення ситуації додаткової орієнтації, яка переходить у творчий процес вироблення нових знань і способів дії, зумовлює розвиток. 
Початок діалогу $є$ початком розвитку, зокрема профресійного. Комунікативні зв'язки між учасниками освітнього процесу мають пріоритетне значення у взаєморозумінні між учасниками педагогічної взаємодії та в досягненні спільної мети. Взаєморозуміння між учасниками педагогічної взаємодії забезпечується процесом взаємоінтерпретування, який есплікується в діалозі. Саме діалог перебуває в контексті особистісних цілей та інтересів його агентів, що робить їх взаємодію більш природною та продуктивною. У цьому контексті вирішальне значення має адаптивне управління, оскільки в його основі лежить діалог між суб'єктом і об'єктом управління при узгодженні цілей.

Аналіз ієрархії зв'язків в освітньому процесі дає змогу зробити висновки, що ефективна робота його структурних підсистем, зокрема в ланці «викладач» - «студентська академічна група», здебільшого залежить від рівня їх комунікативних зв'язків, на основі яких визначається тип управлінської діяльності викладача. Чим вищий рівень діалогічної взаємодії, тим вища продуктивність навчання у студентів і профессіоналізм у науковопедагогічного працівника. На рис. 1 наведена схематична модель взаємодії викладача і студента на засадах адаптивного управління.

Соціально-значущі цілі викладача $\mathrm{V}$ професійні потреби студента

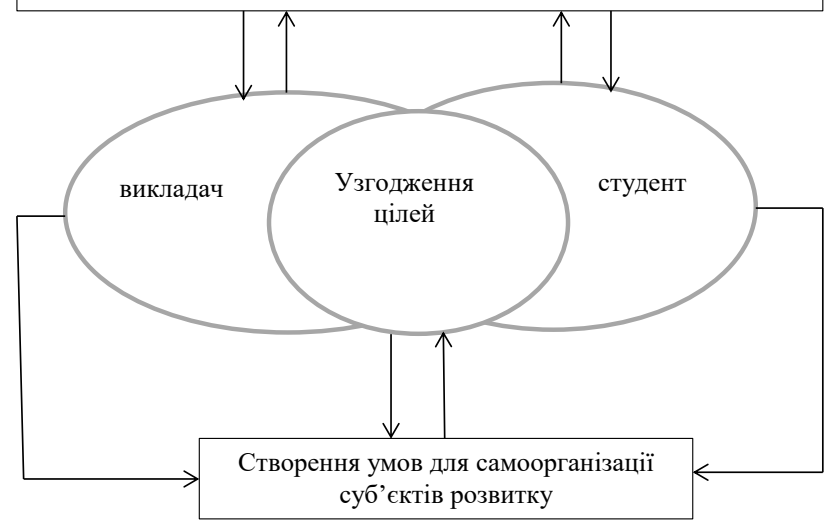

Рис. 1. Схематична модель взаємодії викладача і студента на засадах адаптивного управління

Схематична модель узагальнює процеси адаптивного взаємопристосування з метою виконання визначених цілей.

Розглянемо більш детально умови, які є підґрунтям спрямованої самоорганізації суб'єктів професійного розвитку. Створення умов спрямовується у двох напрямах: практичні заняття та самостійна робота. На основі взаємодії саме у таких видах діяльності викладача і студента відбуваються зміни, які включають такі елементи як зміни у практичному веденні занять, зокрема у системі розподілу ролей під час практичного заняття на основі зміни змісту, який відповідає інтересам сту- дентів щодо їх професійного зростання, та зміни ставлення до самостійної роботи як студентами, так і викладачами, зміни в рівні навченості студентів, зміни в поглядах, переконаннях і співставленні викладача до роботи, зміни у ставленні студента до навчання. Завдяки таким змінам у ставленні до освітньої діяльності як викладачами, так і студентами відбувається професійний розвиток і підвищення мотивації діяльності.

Схематична модель має циклічний характер, в ії основу покладена освітня мета, яка відбивається у змісті, характеристики середовища та варіативності освітнього процесу. Ефективне управління взаємодією відбувається тоді, коли з'являється переконання у викладача в тому, що обрані зміст, методи та технології навчання та організації навчального процесу позитивно вплинули на студента, у результаті їх рівень компетентності підвищується.

Схематична модель взаємозв'язку між професійним розвитком науково-педагогічних працівників і підвищенням рівня навченості студентів ґрунтується на припущенні, що зміни в поглядах і ставленні до роботи викладача спочатку наголошують на важливості усвідомлення самим науково-педагогічним працівником існуючого стану речей та його готовності до змін. Планування дій відбувається на основі пріоритетів, які відбивають погляди та ставлення до роботи самого викладача перед тим, як втілити їх у нову програму дій або нововведення. Таке планування може відбуватися із залученням студентів до процесу планування або перегляду програми дій, що значно підвищує вмотивованість у спільній роботі, оскільки існує значний ступінь довіри з боку студента, що і забезпечує студентоцентристський підхід.

Необхідно зазначити, що результати навченості студентів охоплюють не тільки пізнавальні та навчальні аспекти діяльності викладача, а й більш широке коло інших характеристик, включаючи емоційні, ціннісні, організаційні. Рівень досягнень студентів містить будь-які фрактори, які викладач може використовувати для оцінювання студента та своєї роботи. Тільки після того, як викладач буде впевнений у вірогідності досягнень студентів і своїх нововведень, можна говорити про зміни в його поглядах і ставленні до нової стратегії в роботі [3]. Зростання вмотивованості студента до виконання завдань $€$ показником ефективного управління взаємодією викладача і студента, тому що залучення студента до діяльності, надання йому інструментів прийняття рішень $€$ практичним досвідом для його професійного зростання у подальшому.

Отже, ціннісні основи значно впливають на ступінь управління взаємодією викладача і студента, тому що цінність $€$ справжньою причиною й підґрунтям для досягнення мети. Мета має від- 
повідати цінностям студента (викладача). Розуміючи свої цінності, людина вільна шукати й знайти кращий спосіб задоволення своїх потреб. При дотриманні цінностей зберігається мотивація. Якщо з'ясувати для себе цінність, яка стоїть за метою, то просування до мети перетвориться у задоволення.

Для визначення цінностей викладача і студента було вибрано поширену методику М. Рокіча, яка визначає змістову спрямованість особистості і складає основу її ставлення до навколишнього світу, інших людей, самого себе, а також є підґрунтям основи світосприйняття й ядром мотивації життєвої активності та життєвої фрілософрії. М. Рокіч виокремлює два типи цінностей: термінальні (цінності-цілі), такі, в яких кінцева мета індивідуального існування варта того, щоб до неї прагнути, та інструментальні (цінності-засоби), це такі переконання, у яких певний спосіб дії або якість особистості є переважною у певній ситуації [6].

Для визначення ціннісно-змістової єдності викладачів і студентів як умови їх взаємодії викладачам і студентам було запропоновано заповнити анкету. При порівнянні відповідей у студентів і викладачів здебільшого співпадали визначення більш-менш важливих цінностей. Так, найбільш важливими цінностями першої групи для студентів і викладачів були любов, щасливе сімейне життя та активне життя, щодо другої групи - це чесність (правдивість, щирість), вихованість (гарні манери). До менш важливих можна віднести з першої групи цінностей красу природи та мистецтва (переживання прекрасного у природі та мистецтві), щастя інших (благополуччя, розвиток та удосконалення інших людей, усього народу, людства загалом); до другої групи - непримиренність до недоліків у собі та інших), високі вимоги до життя.

Отже, нами було виявлено основні прагнення як студентів, так і викладачів. Знання про цінності людини дає підґрунтя для розуміння вмотивованості до навчання або викладання. За допомогою виявлення цінностей можна більш якісно спрямовувати людину на результат праці або коригувати цінності щодо потреб суспільства. Так, для безперервної самоосвіти та самоуправління однією 3 необхідних цінностей із першої групи є розвиток (робота над собою, постійне духовне та фрізичне удосконалення), який не $є$ важливим для студентів (за результатами опитування), проте викладачі надають перевагу такій цінності, оскільки можуть спрямовано вплинути на студентів щодо фрормування цінності, яка $€$ важливою для їх подальшого життя. У такий спосіб можна розглянути й інші цінності студентів, які не важливі для них на першому курсі, проте набувають значення на наступних курсах навчання у процесі роботи викладачів зі студентами щодо їх цінностей.
У студентів різних курсів цінності змінюються. Так, цінність першої групи - цікава робота, другої - освіченість, яка була менш важливою для студентів першого курсу, а для студентів другого та третього курсів вона набула актуальності. Може відбуватися і протилежне, якщо для студентів перших курсів була важливою така цінність як розваги, то для студентів третього курсу вона стає менш значущою.

Аналізуючи результати проведеного анкетування, було визначено пріоритети у професійному розвитку викладачів і студентів, що підвищило вмотивованість у роботі і навчанні та близькість у показниках термінальних цінностей і довело їх ціннісно-орієнтовану єдність. Позитивна вмотивованість завжди впливає на якість у діяльності. У нашому випадку можна говорити про цілеспрямований вплив на формування у студента необхідних для суспільства якостей, управління якістю підготовки фрахівців. Проаналізувавши основні цінності студентів і викладачів, можна приймати управлінські рішення щодо взаємодії викладача й студента та їх результативності у роботі та навчанні.

Не менш важливою умовою $є$ встановлення раппору, тобто таких взаємин, які дозволяють викладачу або студенту більше довіряти один одному та інтенсивніше розвиватися. У нашому дослідженні було проведено анкетування та виявлено імедіативність поведінки науково-педагогічних працівників і студентів [5].

Дослідження імедіативної поведінки викладачів і студентів широко представлено, наприклад, у зарубіжній педагогіці й соціальній психології. Існує низка робіт, які висвітлюють взаємозв'язок імедіативності викладача й студента (Й. Андерсен, А. Мехрабіан та інші). Предметом дослідження були особливості імедіативної (вербальної і невербальної) поведінки викладачів іноземних мов (6 осіб), які оцінював студентський корпус (200 осіб) за допомогою запропонованого тестового фрормату. Подібне дослідження доцільне й вчасне, оскільки дає змогу простежити та об'єктивно довести, які саме елементи імедіативної поведінки викладачів $€$ найбільш важливими 3 погляду організації роботи в аудиторії по лінії «викладач - студент». Загальний висновок щодо статистичного аналізу рівня імедіативності викладачів є таким: у цьому дослідженні у 90\% випадків рівні імедіативності викладачів статистично збігаються, лише в 10\% (6 із 60) випадків вони є різними.

Аналіз імедіативних характеристик за класами показав, що головною для студентів характеристикою викладача $€$ та, що він ставить запитання 3 метою залучення до розмови про предмет спілкування. ІІї числове значення склало 3,187 бали. Найбільш значуща для студентів невербальна характеристика викладача - це те, що викладач дивиться 
на аудиторію, звертаючись до неї (3,241 бали). Найбільшою негативною невербальною характеристикою викладача можна вважати те, що він / вона дивляться на дошку або у свої нотатки, коли говорять (1,070 балів), звертання до студентів монотонним нудним голосом (0,835 балів) виявилося найменш негативним у цій групі.

Отже, сукупні результати статистичної обробки дають змогу об'єктивно визначати пріоритетні можливості вербальної та невербальної поведінки викладачів у студентській аудиторії, що поліпшить мікроклімат і стосунки між викладачем і студентами, посилить умотивованість до навчання та досягнення вищих результатів у навчанні.

Необхідно зазначити, що у процесі залучення діалогічної взаємодії нами було використано інструментарій, запропонований Г. Маклін, Б. Янг, К. Куо, Е. Толберт, К. Ларкіним [4]. Зауважимо, що традиційно контроль є важливою функцією управління, варіюються тільки його ступені та стилі. Якщо стиль управління акцентуються на децентралізації та розподілі обов'язків між командами, сила управлінського контролю підпорядкування зменшується.

Вміння діалогічної взаємодії є дуже складними для формування в управлінні через наявність критичного обсягу відповідальності у структурі організації. Діалогічна взаємодія перевіряється за допомогою визначення рівня сорормованості таких управлінських вмінь, які демонструють характеристики ефрективної взаємодії: систему відкритої комунікації з іншими, командний підхід у роботі, значимість людей щодо виконання завдань, урахування неоднорідної природи робочого середовища 3 метою розвитку підлеглих і підвищення якості виконання роботи.

Запропонована структура має чотири основні складники: керівник, співробітники, які працюють 3 керівником, необхідне завдання для виконання та робоче середовище. Через складність відстеження ступеня підлеглості анкетування проводилося в межах одного закладу освіти. Отже, тільки у взаємозв'язку чотирьох компонентів може відбуватися ефективна діалогічна взаємодія.

Ефективна діалогічна взаємодія відображається у чотирьох аспектах поведінки керівника (викладача 3 обов'язками керівника). По-перше, керівнику необхідно спілкуватися відкрито з усіма, включаючи підлеглих і колег (студентів). По-друге, керівнику необхідно спиратися у роботі на групову роботу, а не на індивідуальну. По-третє, керівнику необхідно оцінювати роботу студентів відповідно до виконаної роботи, а не за іншими параметрами. По-четверте, керівнику необхідно врахувати неоднорідну природу робочого середовища. Результати вимірювалися за запропонованою чотири- фракторною структурою щодо оцінювання вмінь діалогічної взаємодії у викладачів і студентів.

Респондентами були обрані такі аспекти: відкрита комунікація, командна робота, значимість людей та урахування неоднорідності. Наявність таких даних дає змогу для більш скерованої роботи науково-педагогічного працівника і студента, удосконалення педагогічної майстерності викладача та підвищення рівня навченості студента, що сприятиме отриманню задоволення від спільної роботи.

Висновки. Виокремлення організаційно-педагогічних умов щодо ефективного управління взаємодією викладача і студента, що безпосередньо впливає на якість підготовки фрахівців, є підґрунтям для подальшого удосконалення організації навчального процесу. Практичне виконання умов управління взаємодією викладача і студента отримало свої результати: викладачі можуть відчувати зміни у результатах навчання студентів з іноземної у нашому університеті, зросла зацікавленість предметом - іноземну обирає як вибіркову дисципліну все більша кількість студентів, активність студентів з використання іноземної в освітніх цілях теж зросла, про що свідчать виступи на конференціях іноземною, написання наукових робіт, друкування тез доповідей іноземними мовами, а також збільшилася кількість студентів, які отримали міжнародний сертисрікат щодо рівня володіння іноземною мовою.

Зазначена тема має широкий спектр вивчення, який не можливо викласти в окремо взятій статті, тому вона $€$ невичерпаною. Виокремлення технологій, які прискорять зміни в освітньому процесі, а саме в управлінні взаємодією викладача і студента, є питанням, що потребує подальшого вивчення.

БІБЛІОГРАФІЧНИЙ СПИСОК:

1. Адаптивне управління: міжгалузеві зв'язки, науково-прикладний аспект : колективна монографія / Г.В. Єльникова, Т.А. Борова, 3.В. Рябова та інші. [За заг. та наук. редакцією д-ра пед. наук, профресора Г.В. Єльникової]. Харків : Мачулін, 2017. 564 с.

2. Гончар О.В. Педагогічна взаємодія учасників навчального процесу в системі вищої освіти України (історико-педагогічний аспект) : монографрія. Харків : ХНАДУ, 2011. 424 c.

3. Guskey T.R. Research Needs to Link Professional Development and Student Learning. Journal of Staff Development. NSDC. 1997. № 18(2) P. 36-40.

4. McLean Yang G.B, Kuo Ch., Tolbert A., Larkin C. Measuring Managerial Coaching Skills. Human Resource Development Quarterly. 2005. Vol. 16, № 2. P. 157-178.

5. Mehrabian A. Nonverbal Communication. Chicago : Aldine, 1972. 217 p.

6. Rokeach M. The Nature of Human Value. N.-Y. : Free Press, 1973. 364 p. 